\title{
Основни критерии и методи на изследване при подбора на кандидати за кохлеарна имплантация
}

Main criteria and methods for investigation in the selection of cochlear implant candidates

\author{
К. Асенова ${ }^{1}$ Хр. Златанов¹, Ст. Стоянов², В. Цветков ${ }^{1}$ Л. Зеленска \\ ${ }^{1} В \mathrm{MA}-$ - УНГ-клиника 2 \\ гМИ - МВР - УНГ-клиника
}

\author{
K. Asenova`, Hr. Zlatanov, St. Stoyanov², V. Tzvetkov', L. Zelenska` \\ ${ }^{1}$ MMA - ENT Clinic, \\ ${ }^{2} \mathrm{MIMI}-$ ENT Clinic
}

\begin{abstract}
Cochlear implantation is a routine method for treatment of deafness with proven effectiveness, which has wide application in the developed world. The success of the operation depends on the right patient selection, precise surgical intervention and active postoperative rehabilitation. In the paper are described the main stages and criteria for patients selection. The protocols for setup and postoperative rehabilitation are discussed.

For achievement of maximal results from cochlear implantation are necessary the joint efforts of highly qualified specialists, parents and pedagogues.
\end{abstract}

Keywords: cochlear implantation, patient selection, setup, rehabilitation.

\section{Резюме}

Кохлеарната имплантация е рутинен метод на лечение на глухотата с доказана ефективност, намерил широко приложение във високоразвитите страни. Успехът на операцията се определя от правилния подбор на пациентите, прецизността на хирургичната интервенция и активната следоперативна рехабилитация. В статията са описани основните етапи и критерии за подбор на пациенти. Разгледани са протоколите за настройка и следоперативна рехабилитация.

За реализирането на максимален ефект от кохлеарната имплантация са необходими съвместните усилия на висококвалифицирани специалисти, родители и педагози.

Ключови думи: кохлеарна имплантация, подбор на пациенти, настройка, рехабилитация.
$\mathrm{K}$ охлеарната имплантация е рутинен метод на лечение на глухотата с доказана ефективност, намерил широко приложение във високоразвитите страни. В България приоритетите са насочени към децата. От няколко години е въведена клинична пътека „,кохлеарна имплантация при лица под 18 год.“.

Успехът на операцията се определя от правилния подбор на пациентите, прецизността на хирургичната интервенция и активната следоперативна рехабилитация. Ето защо решението за имплантация се взема от мултидисциплинарен екип, състоящ се от оториноларинголог, аудиолог, сурдопедагог и специалист по говорна рехабилитация.

Съществуват редица изисквания при подбора на кандидатите за кохлеарна имплантация. На първо място е степента на слуховото увреждане. Подходящи за кохлеарна имплантация са деца с практическа глухота, както и тежко чуващи, при които слухопротезирането не е дало задоволителен резултат. По отношение на възрастните като задължително условие е да са постлингвално оглушали. Оптималната възраст за операция на деца е между 1 и 3 години, до 10 г. се счита, че все още са подходящи за имплант, а след тази възраст се имплантират само постлингвално оглушали или деца с прогресивна загуба на слуха. Поставянето на имплант на деца над 10-годишна възраст с прелингвална глухота не е абсолютно противопоказано, но в тези случаи се взимат под внимание други фактори, като опитьт със слухов апарат и резултатите не са така добри. 
Първият етап от предоперативната оценка и селекция на кандидатите за имплант се състои от две визити и включва аудиологична и УНГ-консултация, т.е. обстойна анамнеза, преглед от УНГ-специалист и някои аудиологични изследвания - тонална прагова аудиометрия, импедансметрия и ако е възможно, оценка на говорното развитие на детето. В случай, че се установят проблеми със слуха, следва хоспитализация и детайлно изследване на слуха. Един от основните му етапи е щателно снетата анамнеза, която дава информация за евентуалната причина за глухота, до каква степен това се е отразило на комуникативните възможности на детето и респективно на неговото развитие. В повечето случаи родителите установяват, че детето има проблем със слуха между 6 месеца и 1 година, а нерядко доста по-късно - едва когато детето е над 3-годишна възраст и не говори.

От особена важност при снемане на анамнезата са данните за серозен отит или рецидивиращ среден отит, тъй като те могат да имат отношение към намаления слух, а изискват и предварително лечение преди кохлеарна имплантация.

Анамнестичните данни все още си остават основният начин за установяване причината за глухота. Голямо значение се отдава на усложнения на бременността и раждането, както и на инфекциите в неонаталния период. Фамилна анамнеза за случаи на глухота в семейството също трябва да се има предвид, но случаите на наследствена глухота са по-редки. В някои случаи глухотата може да е част от синдромно заболяване. Най-често се касае за синдрома на Waardenburg.

Според литературните данни почти в половината от случаите на невросензорна глухота се касае за придобита глухота вследствие на усложнена бременност и раждане или постнатални инфекции. Менингитът и употребата на ототоксични медикаменти са сред най-честите причини за постлингвална глухота в детската възраст.

При констатиране на намален слух, в зависимост от степента на намалението, се препоръчва на детето да носи слухов апарат или директно се насочва за операция. Според българското законодателство на децата с намален слух се полагат по 2 броя дигитални слухови апарати на всеки 3 години, които се отпускат от социалното министерство след издаден протокол за слухопротезиране.

Водеща роля при селекцията на децата за кохлеарна имплантация има аудиологичното изследване. Праговете на чуване трябва да са много точно определени чрез обективни и поведенчески тестове. Един от най-често използваните обективни методи на изследване е ABR (Auditory Brainstem
Responses). Изследването се провежда под анестезия, като след стимулация с шум с честоти в говорния диапазон и с различна сила на звука, най-често над 70 децибела, се регистрират слухови стволови евокирани потенциали със съответна форма и латентни времена. Това е метод на избор при изследване на деца под 2-годишна възраст, тъй като не изисква участие на детето. Друг метод на изследване, който се използва рутинно в УНГ-клиниката при BMA, са отоакустичните емисии. Те са по-скоро скринингов метод, тъй като позволяват регистриране на загуба на слуха над 40 децибела. Към задължителните аудиологични изследвания спада и тимпанометрията и изследването на стапедиус рефлекс. Тимпанометрията дава информация за налягането в средното ухо, а стапедиус рефлексът е допълващ метод на изследване специално при децата и има малка информативна стойност без останалите методи за аудиологично изследване. Обикновено гореизложените изследвания се предшестват от редица поведенчески тестове, като спонтанна реакция на звук, игрова аудиометрия и поведенческа аудиометрия в свободно звуково поле. За определяне на степента на намаление на слуха при децата, особено под 2-годишна възраст, е задължително провеждането на всички гореизложени изследвания. В случаите с практическа глухота преди предприемане на оперативно лечение задължително се прави СТ на темпоралната кост с висока резолюция. Проследяват се състоянието на трите извивки на кохлеята, полуокръжните канали, лицевият нерв, каротидния канал, сигмоидния синус, средното ухо и клетьчната система на процесус мастоидеус. СТ-изследването е необходимо с оглед превенция на усложнения по време на операцията, дължащи се на аномалии в анатомията на темпоралната кост.

При констатиране на намален слух в зависимост от степента на намалението се препоръчва на детето да носи слухов апарат или директно се насочва за операция. Слухопротезиране се препоръчва и при децата с кохлеарен имплант и остатъчен слух на неимплантираното ухо. Според някои автори преди да се пристъпи към кохлеарна имплантация е задължително носенето на слухови апарати поне 6 месеца.

Поставянето на кохлеарен имплант се извършва оперативно под обща анестезия. Обичайното времетраене на операцията е между 2 и 3 часа. Правилното функциониране на импланта се проверява интраоперативно. Болничният престой е около 5 дни. Активирането на говорния процесор става приблизително 30 дни след операцията. В зависимост от нуждите на детето първоначал- 
но настройки на параметрите на стимулация се правят поне веднъж месечно, а след достигане на оптималните параметри - два пъти годишно. Времето за достигане на оптималните параметри на стимулация е индивидуално, като при по-малките деца е по-кратко.

Като цяло повечето деца с имплант проговарят около 1 година след поставянето му, като продължават да напредват в развитието си през следващите.

Фактори, влияещи върху говорното развитие на децата, са възрастта на имплантация, продължителността на използване на импланта, наличието на остатъчен слух, предварителният опит със слухов апарат. Редица изследвания сочат, че децата, имплантирани преди 3 години, развиват много по-бързо своите говорни умения. Деца,
1. Barker, E., T. Daniels, R. Dowell, et al. Long term speech production outcomes inchildren who received cochlear implants before and after 2 years of age. 5th European Symposium on Paediatric Cochlear Implantation, Antwerp, Belgium, 2000: 156.

2. Brown, A. M., R. C. Dowell, G. M. Clark, L. F. Martin and B. C. Pyman.. Selection of patients for multiple-channel cochlear implant patient. In: Schindler, R. A. and M. M. Merzenich, eds. Cochlear implants. New York, Raven Press; 1985: 403-406.

3. Busby, P. A., S. A. Roberts, Y. C. Tong and G. M. Clark.. Results of speech perception 588 9. Preoperative Selection and speech production training for three prelingually deaf parents using a multipleelectrode cochlear implant. British Journal of Audiology 25; 1991: 291-302.

4. Clark, G. M. 2002. Learning to understand speech with the cochlear implant. In: Textbook of Perceptual Learning. Fahle, M. and T. Poggio, eds. Cambridge, Mass., MIT Press:147-160.

5. Clark, G. M. and B. C. Pyman. Preoperative medical evaluation. In: Clark, G., R. Cowan and R. Dowell, eds. Cochlear implantation for infants and children. Advances. San Diego, Singular; 1997: 71-82.

6. Dowell, R. C., P. J. Blamey and G. M. Clark. Factors affecting outcomes in children with cochlear implants. In: Clark, G. M., ed. Cochlear implants. XVI World Congress of Otorhinolaryngology Head and Neck Surgery. Bologna, Monduzzi; 1997: 297-303. имплантирани след 7-годишна възраст, като правило имат по-мальк шанс за развитие на адекватен говор. Носенето на слухов апарат от ранна детска възраст, когато пластичността на нервната система е най-голяма, също е благоприятен фактор. Продължителността на използване на импланта също е от значение. По литературни данни 95\% от децата, имплантирани около 1-годишна възраст, посещават обикновени детски градини и се развиват като чуващи деца. Повечето деца, оперирани в периода около 3-та година, ходят в масово училище.

Кохлеарната имплантация е съвременен метод на лечение с много добри потенциални резултати. За реализирането им са необходими съвместните усилия на висококвалифицирани специалисти, родители и педагози.

7. Fryauf-Bertschy, H., R. S. Tyler, D. M. Kelsay, B. J. Gantz and G. G Woodworth. Cochlear implant use by prelingually deafened children: the influenees of age at implant use and length of device use. Journal of Speech and Hearing Research 40; 1997: 183-199.

8. Kim, H.-N., M.-H. Chung, Y.-T. Shim and J.-S. Yoon.. Aided versus implanted speech recognition abilities in severe to profound postlingual deafness. Annals of Otology, Rhinology and Laryngology 104; 1995 $153-154$.

9. Owens, E. and C. C. Telleen.. Speech perception with hearing aids and cochlear implants. Archives of Otolaryngology 107; 1981: 160-163.

10. Rance, G., R. C. Dowell, F. W. Rickards and G. M. Clark.. Evoked potential assessment of children with severe/profound hearing loss: a comparison of steady-state evoked potential (SSEP) and behavioural hearing threshold levels in subjects with absent click evoked auditory brainstem responses (ABR). In: Clark, G. M., ed. Cochlear implants. XVI World Congress of Otorhinolaryngology Head and Neck Surgery Bologna, Monduzzi; 1997: 175-179. 